ALCHEMY Jurnal Penelitian Kimia

Laman resmi: https://jurnal.uns.ac.id/alchemy

\title{
Penentuan Kandungan Fenolik Total Liquid Volatile Matter dari Pirolisis Kulit Buah Kakao dan Uji Aktivitas Antifungi terhadap Fusarium oxysporum
}

\author{
Mashuni Pallawagau ${ }^{\text {a*, Nur Arfa Yanti }}{ }^{\mathrm{b}}$, M. Jahiding ${ }^{\mathrm{c}}$, La Ode Kadidae ${ }^{\mathrm{a}}$, Wahyu \\ Ahwarul Asis ${ }^{\mathrm{a}}$, Fitri Handayani Hamid ${ }^{\mathrm{a}}$ \\ ${ }^{a} J u r u s a n$ Kimia, Fakultas Matematika dan Ilmu Pengetahuan Alam, Universitas Halu Oleo, Kendari, \\ Sulawesi Tenggara \\ ${ }^{b}$ Jurusan Biologi, Fakultas Matematika dan Ilmu Pengetahuan Alam, Universitas Halu Oleo, Kendari, \\ Sulawesi Tenggara \\ ${ }^{c}$ Jurusan Fisika, Fakultas Matematika dan Ilmu Pengetahuan Alam, Universitas Halu Oleo, Kendari, \\ Sulawesi Tenggara \\ * Corresponding author
}

E-mail: mashuni2696@gmail.com

DOI: 10.20961/alchemy.15.1.24678.165-176

Received 19 October 2018, Accepted 13 February 2018, Published Online 01 March 2019

\begin{abstract}
ABSTRAK
Kulit buah kakao (KBK) adalah limbah organik dari hasil olahan buah kakao yang dapat digunakan sebagai sumber senyawa aktif. Kulit kakao mengandung senyawa selulosa, hemiselulosa dan lignin yang dapat terdekomposisi menghasilkan senyawa fenolik. Penelitian ini bertujuan untuk menentukan kandungan fenolik total atau Total Phenolic Content (TPC) dari liquid volatile matter (LVM) hasil pirolisis KBK dan uji aktivitas antifungi terhadap Fusarium oxysporum. Produksi LVM dihasilkan dari metode pirolisis KBK pada suhu $500{ }^{\circ} \mathrm{C}$. Penentuan TPC dengan metode spektrofotometri UV-Vis menggunakan pereaksi FolinCiocalteu (FC) pada panjang gelombang maksimum $765 \mathrm{~nm}$ dengan larutan standar asam galat dan diukur setelah dibiarkan selama 60 menit pada suhu kamar. Uji aktivitas antifungi terhadap $F$. oxysporum dilakukan dengan metode dilusi. LVM dari hasil pirolisis KBK adalah 25,80\% (b/b) dengan TPC 100\% sebesar 2,28 g/L. Pirolisis KBK menghasilkan LVM yang memperlihatkan aktivitas antifungi dengan konsentrasi hambat minimal (KHM) 1\% (v/v) dan konsentrasi bunuh minimal (KBM) 9\% (v/v). Oleh karena itu, LVM KBK memiliki potensi untuk diaplikasikan sebagai fungisida alami.
\end{abstract}

Kata kunci: Antifungi, fenolik, Fusarium oxysporum, kulit buah kakao, liquid volatile matter

\begin{abstract}
Determination of The Total Phenolic Content of Liquid Volatile Matter from Cocoa Pod Husk Pyrolysis and Antifungal Activity Test Against Fusarium oxysporum. The cocoa pod husk (CPH) is an organic waste from the processed cocoa potentially used as source of active compounds. The CPH contains cellulose, hemicelluloses, and lignin compounds that can be decomposed into phenolic compounds. The present study investigated the determination of total phenolic content (TPC) of liquid volatile matter (LVM)
\end{abstract}


of $\mathrm{CPH}$ followed by the antifungal activity test against Fusarium oxysporum. The LVM production was performed by the pyrolysis method at temperature of $500{ }^{\circ} \mathrm{C}$. The determination of TPC was evaluated by the UV-Vis spectrophotometric method using the Folin-Ciocalteu (FC) reagent at maximum wavelength of 765 $\mathrm{nm}$ with the standart solution of gallic acid measured after 60 min reaction at room temperature. The antifungal activity test against $F$. oxysporum was carried out by dilution method. The pyrolysis of $\mathrm{CPH}$ produces LVM of $25.80 \%(\mathrm{~b} / \mathrm{b})$ contained TPC $100 \%$ of $2.28 \mathrm{~g} / \mathrm{L}$. The LVM produced in this study shows antifungal activity with a minimal inhibitory concentration (MIC) $1 \%(\mathrm{v} / \mathrm{v})$ and minimum fungicidal concentration (MFC) 9\% (v/v). Therefore, the LVM CPH produced can be applied as a natural fungicide.

Keywords: Antifungal, cocoa pod husk, Fusarium oxysporum, liquid volatile matter, phenolic

\section{PENDAHULUAN}

Kakao merupakan salah satu komuditas andalan perkebunan Indonesia yang memiliki jumlah produksi yang cukup besar. Salah satu daerah penghasil kakao di Indonesia adalah Provinsi Sulawesi Tenggara dengan luas area perkebunan sebesar 251. 730 Ha dengan total produksi mencapai 157,537 ton (BPS, 2016). Besarnya produksi kakao menghasilkan limbah pertanian berupa kulit buah kakao (KBK) yang belum dimanfaatkan secara optimal. KBK merupakan limbah lignoselulosa yang mengandung komponen utama berupa selulosa 36,23\%, hemiselulosa 1,14\% dan lignin 20-27,95\% (Chen, 2015). Selulosa dan hemiselulosa dipolimerisasi dari monosakarida, yang dapat diubah menjadi gula dalam kondisi tertentu. Lignin adalah polimer aromatik dapat dikonversi menjadi senyawa fenolik (Purnamawati and Budi, 2014). Senyawa fenol merupakan suatu senyawa yang mengandung gugus hidroksil (-OH) yang terikat langsung pada gugus cincin hidrokarbon aromatik. Aktivitas senyawa fenol berasal dari jumlah gugus hidroksil pada cincin benzena. Klasifikasi senyawa fenol yang terkandung dalam tumbuhan yaitu fenol sederhana, benzokuinon, asam fenolat, asetofenon, naftokuinon, xanton, bioflavonoid kumarin, stilben, turunan tirosin, asam hidroksi sinamat, flavonoid, lignan, dan tanin. Flavonoid dan polifenol dapat menghambat pertumbuhan bakteri dan jamur patogen (Guerrero et al., 2012).

Dekomposisi lignin pada kulit kakao dapat menggunakan metode pirolisis. Pirolisis adalah proses pemanasan suatu zat dengan oksigen terbatas sehingga terjadi penguraian komponen-komponen penyusun sampel yang dipanaskan (Hidayat and Qomaruddin, 2015; Wijaya et al., 2014). Pada proses pirolisis energi panas mendorong terjadinya oksidasi sehingga molekul karbon yang kompleks terurai sebagian besar menjadi karbon atau arang dan sisanya berupa asap cair (Liquid Volatil Matter (LVM)) (Yaman, 2004). Komponen kimia LVM hasil pirolisis adalah senyawa amonia, heksana, alkohol, keton, karbonil, asam asetat dan fenolik (Mashuni et al., 2017; Ifa et al., 2018; Jahiding et al., 2017). 
Senyawa fenolik diketahui memiliki sifat antibakteri dan antifungi (LamuelaRaventos et al., 2005). Senyawa tersebut merupakan senyawa metabolit sekunder yang terdapat secara melimpah pada tanaman. Metode yang sering digunakan untuk menganalisis kandungan senyawa fenolik adalah dengan metode Folin-Ciocalteu (Suharto et al., 2017). Berdasarkan penelitian Rachmawaty et al. (2018) senyawa fenolik, flavonoid, tanin, dan terpenoid dari KBK diketahui memiliki aktivitas antimikroba. Senyawa aktif fenol memiliki kemampuan merusak membran sel sehingga terjadi perubahan permeabilitas sel yang dapat mengakibatkan terhambatnya pertumbuhan sel atau matinya sel mikroba.

Jamur Fusarium oxysporum dapat menyebabkan kerusakan pada pengelolaan pertanian yang sangat merugikan bagi petani. F. oxysporum dapat menyerang cabai merah, tomat, kacang panjang, kentang, kubis dan beberapa tanaman lainnya yang akan menyebabkan tanaman layu (Hermanto et al., 2012). Cara yang dilakukan oleh petani untuk mencegah timbulnya penyakit yang diakibatkan oleh jamur $F$. oxysporum biasanya menggunakan pestisida sintetik. Petani umumnya menggunakan pestisida sintetik untuk pengelolaan pertanian karena mudah didapat dan proses penggunaanya sederhana serta hasil yang didapatkan cepat. Namun dibalik keunggulan pestisida sintetik tersebut terdapat beberapa kekurangan, diantaranya menimbulkan pencemaran pada lingkungan karena sulit terurai, meninggalkan sisa residu pada produk pertanian sehingga membahayakan konsumen dan dapat membunuh musuh alami hama (Mashuni et al., 2016). Alternatif untuk mengurangi penggunaan pestisida sintetik yaitu menggunakan pestisida alami (biopestisida).

Biopestisida adalah pestisida alami yang diperoleh baik dari suatu mikroorganisme ataupun ekstrak tanaman tertentu. Biofungisida merupakan salah satu jenis pestisida alami yang digunakan untuk menghambat atau membunuh jamur penyebab penyakit pada tanaman dengan menggunakan komponen aktif yang terdapat pada mikroba ataupun tanaman. Penggunaan biofungisida lebih murah dan ramah lingkungan dibandingkan fungisida sintetik. LVM hasil pirolisis kulit kakao merupakan salah satu alternatif yang dapat dimanfaatkan sebagai bahan dasar untuk membuat biofungisida, dikarenakan KBK mempunyai beberapa kandungan senyawa yang dapat diolah menjadi senyawa aktif yang memiliki sifat antimikroba antara lain dari kelompok senyawa fenol. Pentingnya mendapatkan senyawa aktif dari bahan organik yang ramah lingkungan untuk diaplikasikan sebagai antifungi maka penelitian ini dilakukan dengan tujuan memproduksi 
LVM dengan pirolisis KBK dan menentukan kandungan total fenolik atau total phenolic content (TPC) serta uji aktivitas antifungi terhadap F. oxysporum.

\section{METODE PENELITIAN}

Kulit buah kakao dipisahkan dari bijinya dan dipotong-potong dengan ukuran $\pm 2 \times 2$ $\mathrm{cm}$, kemudian dikeringkan dibawah sinar matahari selama 7-10 hari.

\section{Proses Pirolisis}

Proses pirolisis dilakukan dengan cara sebagai berikut: sampel KBK yang telah kering ditimbang sebanyak $1000 \mathrm{~g}$ kemudian dimasukkan ke dalam reaktor pirolisis yang dilengkapi dengan rangkaian kondensor dan termokopel. Pirolisis dilakukan pada suhu $500{ }^{\circ} \mathrm{C}$ selama $\pm 2-3$ jam (Mashuni et al., 2017a) dengan kecepatan alir pemanasan sebesar $6{ }^{\circ} \mathrm{C} /$ menit. Pirolisis dihentikan setelah tidak ada LVM yang menetes ke penampungan dan akan dihasilkan minyak LVM, tar dan arang. LVM didiamkan selama 24 jam kemudian dilakukan proses penyaringan dengan menggunakan arang aktif dan kertas saring whatman.

\section{Penentuan Kandungan Fenolik Total}

Penentuan kadar total fenolik atau TPC dilakukan dengan mengunakan alat Spektrofotometri UV-Vis dengan menggunakan pereaksi Folin-Ciocalteu (FC) dan $\mathrm{Na}_{2} \mathrm{CO}_{3}$. Konsentrasi fenolik dalam larutan sampel ditentukan dengan menggunakan uji FC. Sampel LVM dibuat dalam konsentrasi $1 \%(\mathrm{v} / \mathrm{v})$. Sebanyak $3 \mathrm{~mL}$ larutan masingmasing sampel dan larutan standar asam galat $(5,10,30,50,70$ dan $90 \mathrm{mg} / \mathrm{L})$ dimasukkan ke dalam tabung reaksi. Selanjutnya, larutan ditambahkan $15 \mathrm{~mL}$ reagen $\mathrm{FC} 10 \%$ kemudian dikocok hingga homogen. Setelah itu larutan tersebut, ditambahkan larutan $\mathrm{Na}_{2} \mathrm{CO}_{3}$ 7,5\% $12 \mathrm{~mL}$ kemudian dikocok dan dibiarkan selama 60 menit pada suhu kamar $(27 \pm 0,5){ }^{\circ} \mathrm{C}$. Absorban larutan sampel dan larutan standar diukur dengan spektrofotometer UV-Vis pada panjang gelombang absorban maksimum $765 \mathrm{~nm}$. Pengukuran absorban dilakukan secara triplo Hasil pengukuran ini dinyatakan sebagai g/L ekuivalen asam galat (Al-Owaisi et al., 2014).

\section{Uji Konsentrasi Hambat Minimum (KHM) dan Konsentrasi Bunuh Minimum (KBM)}

Metode difusi biasa disebut juga dengan peracunan media. Variasi konsentrasi KBK dibuat 6 konsetrasi dengan cara masing-masing dari ekstrak LVM (100\%) dipipet dengan volume 1, 3, 5, 7, 8 dan $9 \mathrm{ml}$ yang diencerkan dengan $100 \mathrm{ml}$ air sehingga diperoleh variasi 
konsentrasi1, 3, 5, 7, 8 dan 9\% (v/v). Pengujian dilakukan menggunakan metode difusi dengan cara jamur $F$. oxysporum ditanam pada media PDA padat yang telah dicampur dengan ekstrak LVM hasil pirolisis KBK dengan konsentrasi 1, 3, 5, 7, 8 dan 9\% dan air sebagai kontrol negatif. Pengamatan dilakukan terhadap penghambatan pertumbuhan jamur $F$. oxysporum sejak hari pertama setelah isolasi sampai pertumbuhan jamur $F$. oxysporum pada kontrol memenuhi cawan petri, kemudian diukur diameter koloni jamur. Penghambatan pertumbuhan jamur $F$. oxysporum dapat dihitung menggunakan rumus (Sharma and Pandey, 2014 dan Pangestu et al., 2014):

$$
\mathrm{P}=\frac{(\mathrm{a}-\mathrm{b})}{\mathrm{a}} \times 100 \%
$$

Keterangan:

$$
\begin{aligned}
& \mathrm{P}=\text { penghambatan } \\
& \mathrm{a}=\text { diameter koloni jamur pada kontrol } \\
& \mathrm{b}=\text { diameter koloni jamur pada perlakuan }
\end{aligned}
$$

\section{HASIL DAN PEMBAHASAN}

\section{Hasil Pirolisis Kulit Kakao}

Proses pirolisis menghasilkan cairan yang berbau menyengat, terdiri dari dua lapisan yaitu lapisan atas berwarna hitam sebagai LVM dan bagian bawah berwarna hitam kental sebagai tar. Selain itu, juga diperoleh residu berupa arang dan gas-gas yang tidak dapat terkondensasikan. Gas yang dihasilkan dari proses pirolisis tidak dapat terkondensasi oleh pendingin, sehingga tidak tertampung pada penampungan cairan. Sebagian dari gas-gas tersebut terjebak pada penampungan dan yang lain terlepas dari penampungan sehingga keluar melalui pipa penyalur asap dan lepas keatmosfer. Berikut data hasil rendamen pirolisis yang telah dilakukan disajikan pada Gambar 1.

Gambar 1 memperlihatkan secara umum rendamen hasil pirolisis KBK yang terkecil adalah tar sebesar 3,20\% kemudian berturut-turut LVM 25,80\% dan arang sebesar 27\% sehingga kalau total $100 \%$ maka diperoleh rendamen zat terbuang adalah $44 \%$. Banyaknya zat yang terbuang bisa disebabkan oleh beberapa hal, antara lain dipengaruhi oleh kecepatan alir panas yang digunakan dimana semakin cepat alir panas yang digunakan maka semakin cepat proses penguapan terjadi sehingga hasil pirolisis banyak yang menguap menjadi gas dibanding yang terkondensasi menjadi LVM. 


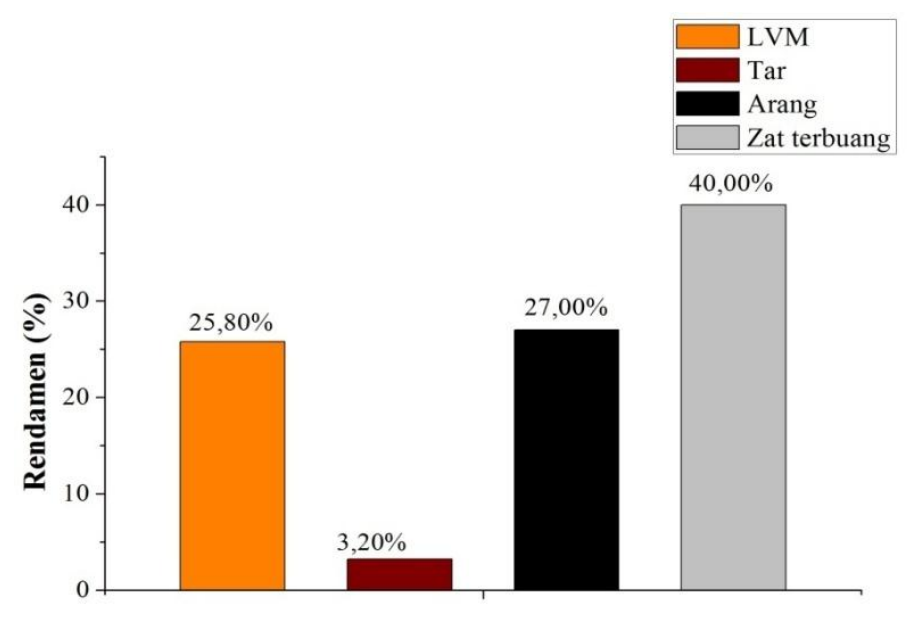

Gambar 1. Rendemen hasil pirolisis kulit buah kakao

\section{Analisis Total Phenolic Content (TPC)}

Penentuan TPCLVM dengan metode FC menggunakan spektrofotometer UV-Vis. Asam galat digunakan sebagai standar senyawa fenolik untuk menetapkan kandungan senyawa fenolik total. Prinsip dari metode FC adalah terbentuknya senyawa kompleks berwarna biru yang dapat diukur pada panjang gelombang $765 \mathrm{~nm}$ (Agbor et al., 2014). Ion fenolat dibentuk melalui disosiasi proton senyawa fenolik, reaksi ini hanya dapat terjadi dalam kondisi basa, sehingga digunakan natrium karbonat sebagai basa (Gambar 2).<smiles>Oc1ccccc1</smiles>

Senyawa fenol

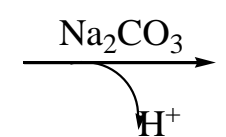

Ion Fenolat

Gambar 2. Pembentukan ion fenolat dalam suasana basa (Agbor et al., 2014)

Ion fenolat bereaksi dengan reagen FC membentuk kompleks molybdenumtungsten berwarna biru yang dapat dideteksi dengan spektrofotometer. Warna biru yang dihasilkan menggambarkan jumlah kompleks yang terbentuk, sehingga semakin tinggi kandungan fenolik dalam suatu ekstrak, semakin pekat warna biru yang dihasilkan (Apsari and Susanti, 2011). Reaksi tersebut bedasarkan pada Gambar 3.

Asam galat digunakan sebagai larutan standar karena merupakan substansi yang stabil serta merupakan senyawa yang umum digunakan sebagai standar dalam penentuan kandungan senyawa fenolik. Pembuatan kurva standar dilakukan untuk menghitung konsentrasi senyawa fenolik pada LVM. Kurva standar yang dihasilkan dari proses pengukuran menunjukkan adanya hubungan linearitas antara variabel terikat (konsentrasi 
larutan standar) dan variabel bebas (absorban). Pengujian linearitas menggunakan persamaan garis lurus $\mathrm{y}=\mathrm{ax}+\mathrm{b}$ (a adalah slope dan $\mathrm{b}$ adalah intersep).

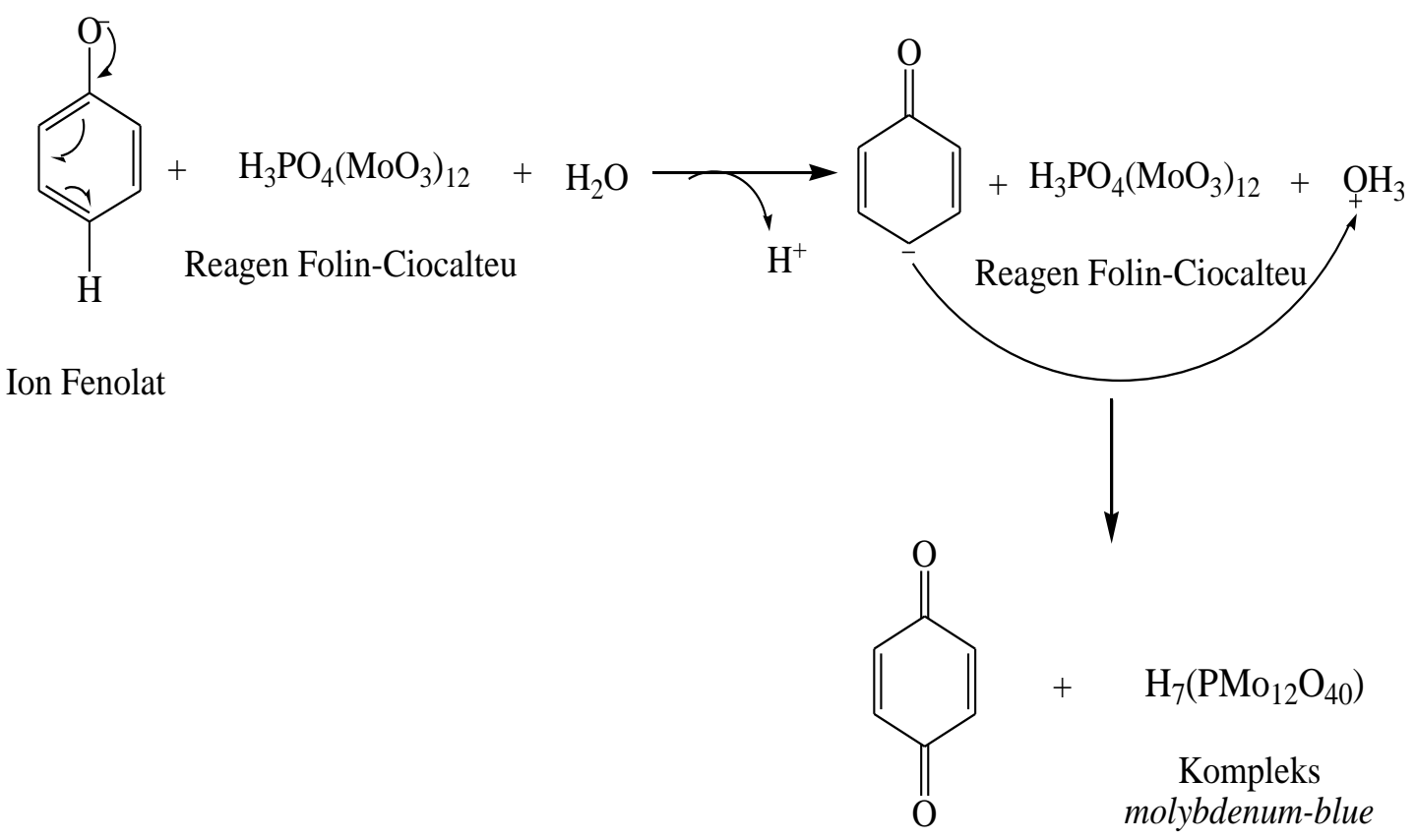

Kuinon

Gambar 3. Reaksi senyawa fenolik dengan pereaksi Folin-Ciocalteu (Apsari and Susanti, 2011)

Hasil pengukuran terlihat bahwa semakin tinggi konsentrasi larutan maka semakin meningkat pula absorbans yang dihasilkan. Persamaan kurva regresi linier dari kurva kalibrasi larutan standar asam galat diperoleh koefisien korelasi dengan nilai $\mathbf{R}^{2}=0,9981$. Pengukuran larutan standar dengan variasi konsentrasi diperoleh persamaan regresi linier y $=0,009 x+0,0077($ Gambar 4).

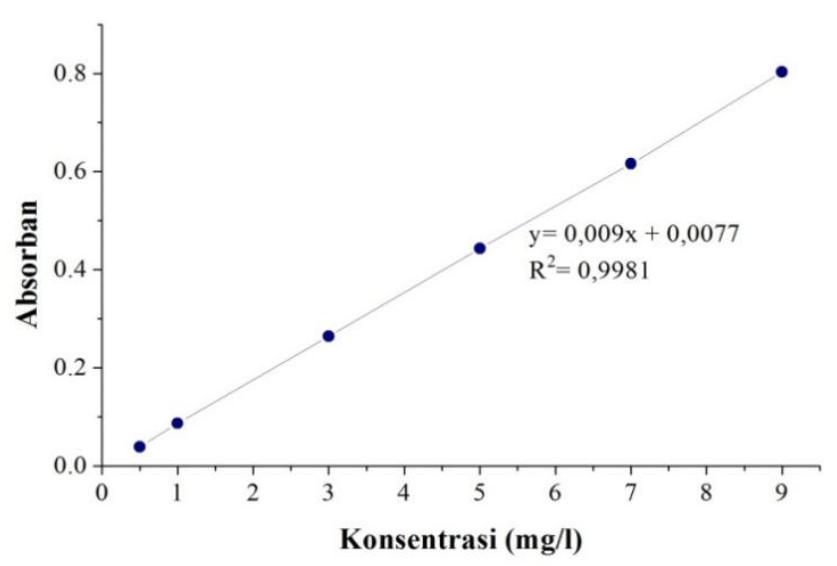

Gambar 4. Kurva kalibrasi larutan standar asam galat 
Analisis kandungan fenolik pada sampel LVM dilakukan setelah memasukkan nilai absorban yang diperoleh menggunakan metode FC pada kurva kalibrasi Gambar 4. Nilai absorban rata-rata LVM KBK yaitu 0,2133 (Tabel 1). Berdasarkan hasil perhitungan dari persamaan regresi diperoleh TPC dari LVM sebesar 22,84 mg/L dalam konsentrasi $1 \%$, sehingga dalam konsentrasi 100\% TPC LVM KBK sebesar 2,28 g/L. Hal ini menunjukan LVM dari KBK mengandung senyawa fenolik cukup tinggi untuk dapat diaplikasikan pada uji penghambatan terhadap pertumbuhan jamur $F$. oxysporum.

Tabel 1. Konsentrasi fenolik total LVM KBK

\begin{tabular}{cccc}
\hline Pengukuran ke- & Absorban & $\begin{array}{c}\text { Konsentrasi fenolik dalam 1\% } \\
(\mathrm{mg} / \mathrm{L})\end{array}$ & $\begin{array}{c}\text { TPC 100\% } \\
(\mathrm{g} / \mathrm{L})\end{array}$ \\
\hline $\mathrm{n}_{1}$ & 0.2100 & 22,4778 & 2,25 \\
$\mathrm{n}_{2}$ & 0.2120 & 22,7000 & 2,27 \\
$\mathrm{n}_{3}$ & 0.2180 & 23,3667 & 2,34 \\
Rata-rata & 0.2133 & 22,8481 & 2,28 \\
\hline
\end{tabular}

Senyawa fenolik berasal dari degradasi termal lignin yang menjadi salah satu komponen penyusun KBK. Menurut penelitian Wijaya et al. (2017), limbah kakao mengandung selulosa 17,27\%, lignin 52,02\% dan hemiselulosa 19,56\%. Kandungan senyawa pada LVM bervariasi tergantung dari jenis bahan, kadar air dan suhu yang digunakan pada saat proses pirolisis. Hasil penelitian Karim et al. (2014), TPC KBK berkisar antara 46 to $57 \mathrm{mg}$ GAE/g. Menurut penelitian Mashuni et al. (2017b), hasil karakterisasi gas chromatography (GC) LVM hasil pirolisis $\mathrm{KBK}$ pada suhu $500{ }^{\circ} \mathrm{C}$ mengandung senyawa amonia, heksana, alkohol, keton, asam asetat dan fenolik. Turunan senyawa fenolik dalam KBK hasil pirolisis yaitu 2-Methoxypenol dan phenol.Senyawa fenolik dan turunanya efektif digunakan sebagai bahan baku herbisida, insektisida, antioksidan, dan bahan kimia lainnya (Rappoport, 2004). Banyaknya komponen senyawa yang terkandung dalam LVM KBK efektif digunakan sebagai antifungi terhadap $F$. oxysporum.

\section{Analisis Konsentrasi Hambat Minimum (KHM) dan Konsentrasi Bunuh Minimum (KBM) LVM Terhadap Jamur F. oxysporum}

Metode dilusi dilakukan untuk mengetahui KHM dan KBM pada sampel LVM dari pirolisis KBK terhadap jamur $F$. oxysporum. Hasil penelitian pada kontrol negatif menunjukkan koloni jamur memenuhi media pada hari ke-7 setelah inkubasi. Variasi konsentrasi yang digunakan untuk ekstrak LVM yaitu 1, 3, 5, 7, 8 dan 9\% (v/v). Terlihat 
dari Gambar 5 bahwa makin tinggi konsentrasi yang digunakan maka makin sedikit pertumbuhan koloni jamur $F$. oxysporum yang terbentuk.

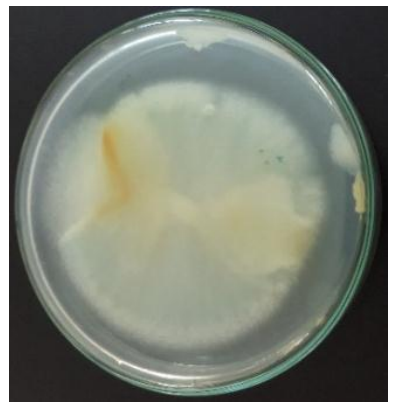

(a)

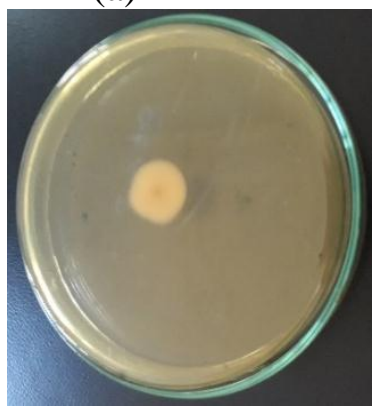

(e)

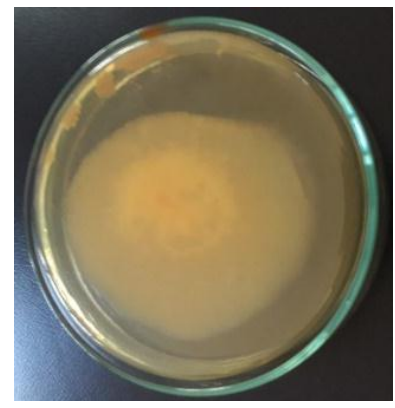

(b)

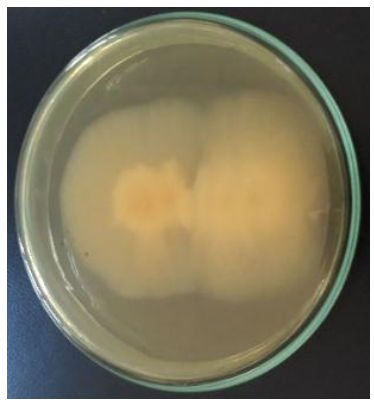

(c)

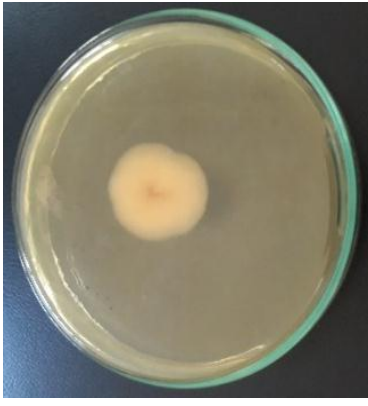

(d)

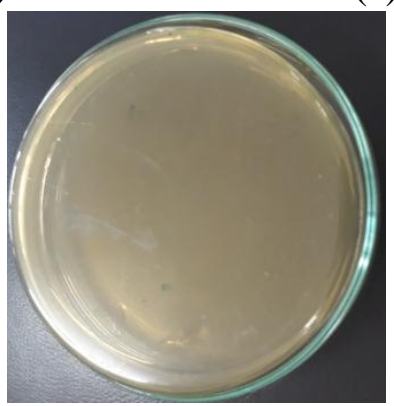

(f)

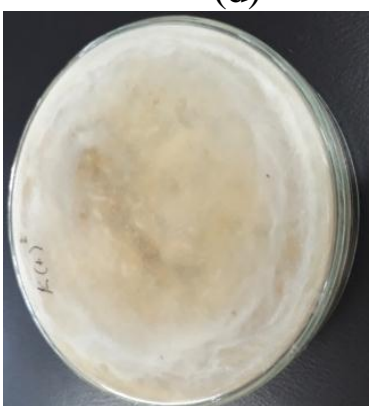

$(\mathrm{g})$

Gambar 5. Hasil uji KHM dan KBM LVM kulit kakao terhadap jamur $F$. oxysporumpada beberapa konsentrasi setelah 7 hari pengamatan (a) 1\%; (b) 3\%; (c) $5 \%$; (d) $7 \%$; (e) $8 \%$; (f) $9 \%$ dan (g) kontrol negatif (air)

Hasil uji KHM dan KBM yang ditunjukkan pada Gambar 5, memperlihatkan bahwa jika dibandingkan dengan kontrol negatif, pertumbuhan koloni jamur $F$. oxysporum telah dapat dihambat oleh LVM KBK konsentrasi terkecil yang dipelajari pada penelitian ini. Oleh karena itu, konsentrasi 1\% LVM merupakan konsentrasi hambat minimum (KHM). LVM pada konsentrasi 9\% terlihat tidak terdapat aktivitas pertumbuhan koloni jamur sehingga disimpulkan bahwa konsentrasi 9\% merupakan konsentrasi bunuh minimum (KBM). Konsentrasi LVM pada KBM dapat diaplikasikan sebagai biofungisida. Hasil pengamatan uji aktivitas antijamur LVM terhadap jamur $F$. oxysporum disajikan dalam tabel 2 berikut:

Tabel 2. Aktivitas anti jamur LVM terhadap jamur Fusrium oxysporum

\begin{tabular}{cccc}
\hline No & Konsentrasi LVM $(\%)$ & Diameter Koloni $(\mathrm{cm})$ & Penghambatan $(\%)$ \\
\hline 1 & Kontrol negatif (air) & 9,00 & 0 \\
2 & 1 & 6,43 & 28,50 \\
3 & 3 & 6,10 & 32,20 \\
4 & 5 & 5,37 & 59,60 \\
5 & 7 & 2,50 & 72,20 \\
6 & 8 & 1,50 & 83,30 \\
7 & 9 & 0 & 100 \\
\hline
\end{tabular}


Berdasarkan hasil pengamatan dan perhitungan yang ditampilkan pada Tabel 1, LVM pada konsentrasi $8 \%$ menghasilkan aktivitas anti jamur dengan penghambatan sebesar $83,30 \%$ sedangkan pada LVM konsentrasi $9 \%$ jamur $F$. oxysporum tidak tumbuh lagi atau dapat dikatakan memiliki daya penghambatan $100 \%$ sehingga pada konsentrasi ini LVM sudah dalam kategori membunuh jamur $F$. oxysporum. Semakin tinggi konsentrasi LVM maka makin baik pula daya hambat yang diberikan sehingga dapat dikatakan bahwa LVM memiliki kemampuan untuk menghambat pertumbuhan jamur $F$. oxysporum.

Senyawa fenolikyang terkandung dalam LVM dapat menyebabkan koagulasi protein sel mikroba, sehingga menyebabkan penghambatan pertumbuhan mikroba. Koagulasi protein akan mengganggu komponen penyusun peptidoglikan pada sel mikroba yang menyebabkan lapisan dinding sel tidak terbentuk secara utuh, sehingga menyebabkan kematian sel. Senyawa fenolik akan berinteraksi dengan protein membran sel mikroba melalui proses adsorbsi dengan cara terikat pada bagian hidrofilik membran sel. Senyawa fenolik selanjutnya akan masuk ke dalam membran sel dan menyebabkan presipitasi protein sel. Hal tersebut mengganggu permeabilitas membran sel, sehingga membran sel dapat mengalami lisis (Mulyatni et al., 2012). Berdasarkan hal tersebut maka dapat dikatakan bahwa LVM memiliki potensi sebagai biofungisida terhadap jamur $F$. oxysporum. Jamur $F$. oxysporummerupakan jamur yangdapat menyerang cabai merah, tomat, kacang panjang, kentang, kubis dan beberapa tanaman lainnya sehingga menyebabkan tanaman layu (Hermanto et al., 2012).

\section{KESIMPULAN}

Kadar fenolik total LVM hasil pirolisis kulit buah kakao diukur dengan metode Folin-Ciocalteu menggunakan alat spektrofotometri UV-Vis diperoleh 2,28 g/L. Konsentrasi hambat minimum (KHM) LVM kulit kakao hasil pirolisis yang didapatkan dari hasil uji antijamur dengan mengunakan metode dilusi yaitu $1 \%$ dan konsentrasi bunuh minimumnya yaitu 9\% dengan masing-masing persen penghambatan $28,50 \%$ dan $100 \%$, sehingga LVM pada konsentrasi 9\% dapat diaplikasikan sebagai fungisida alami.

\section{UCAPAN TERIMAKASIH}

Penulis mengucapkan terimakasih kepada Kementerian Riset, Teknologi dan Pendidikan Tinggi bekerjasama dengan Universitas Halu Oleo (UHO) yang telah mendanai 
riset ini melalui Program Penelitian Prioritas NasionalMasterplan Percepatan dan Perluasan PembangunanEkonomi Indonesia 2011-2025 (PENPRINAS MP3EI 2011-2025) dan Penelitian Strategis Nasional-Institusi (PSN-Institusi) tahun anggaran 2017-2019.

\section{DAFTAR PUSTAKA}

Agbor, G.A., Joe, A.V. and Patrick, E.D., 2014. Folin-Ciocalteu Reagent for Polyphenolic Assay. International Journal of Food Science, Nutrition and Dietetics (IJFS) 3(8), 147-156.

Al-Owaisi, M., Nora, A., and Shah, A.K., 2014. GC-MS Analysis, Determination of Total Phenolics, Flavonoid Content and Free Radical Scavenging Activities of Various Crude Extracts of Moringa peregrine (Forssk.) Fiori Leaves. Asian Pacipic Journal Tropical Biomedicine 4(12), 964-970. doi: 10.12980/APJTB.4.201414B295.

Apsari, P.D., and Susanti, H., 2011. Perbandingan Kadar Fenolik Total Ekstrak Metanol Kelopak Merah dan Ungu Bunga Rosella (Hibiscus sabdariffa Linn) secara Spektrofotometri. Prosiding Seminar Nasional Home Care, Fakultas Farmasi dan Kesehatan Masyarakat UAD, Yogyakarta.

Badan Pusat Statistik (BPS) Sultra, 2016. Potensi Kakao di Sulawesi Tenggara. http://regionalinvestment.bkpm.go.id (diakses pada 27 April 2016).

Chen, H., 2015. Chemical composition and structure of natural lignocellulosesin Lignocellulose Biorefinery Engineering. Woodhead Publishing, Cambridge.

Guerrero, L., Castillo, J., Quiñones, M., Vallvé, S.G., Arola, L. and Pujadas, G., 2012. Inhibition of Angiotensin-Converting Enzyme Activity by Flavonoids StructureActivity Relationship Studies. PLOS One 7(11), 1-11. doi: 10.1371/journal.pone.0049493.

Hermanto, C., Jumjunidang, Edison, and Riska, 2012. Penyakit Layu Fusarium pada Tanaman Pisang di Provinsi VAD: Sebaran dan Identifikasi Isolat Berdasarkan Analisis Vegetative Compatibility Group. Jurnal Hortilkultura 22(2), 165-172.

Hidayat, T., and Qomaruddin, 2015. Analisa Pengaruh Temperatur Pirolisis dan Bahan Biomassa Terhadap Kapasitas Hasil pada Alat Pembuat Asap Cair. Prosiding SNS ke-6 Tahun, Fakultas Teknik, Universitas Wahid Hasyim, Semarang. pp 29-34.

Ifa, L., Setiawati, Y., Mandasini, Zakir, S., Nurjannah, dan Andi, R., 2018. Production of Phenol From Liquid Smoke Resulted by the Pyrolysis of Cashew Nut Shells, Earth and Environmental Science 175, 1-5.doi:10.1088/1755-1315/175/1/012033.

Jahiding, M., Mashuni, Ilmawati, W.O.S., Ermawati, Jumiati, A. and Riskayanti, S.S., 2017. Characterization of Coconut Shell Liquid Volatile Matter (CS-LVM) by Using Gas Chomatroghaphy. Journal of Physics 846, 1-7. doi:10.1088/17426596/846/1/012025.

Karim, A.A., Azlan, A., Ismail, A., Hashim, P., Gani, S.S.A., Zainudin, B.H., and Abdullah, N.A., 2014. Phenolic composition, antioxidant, anti-wrinkles and tyrosinase inhibitory activities of cocoa pod extract. BMC Complementary and Alternative Medicine 14(1), 381. 
Lamuela-Raventos, R.M., Romero-Perez, A.I., Andres-Lacueva, C., and Tornero, A., 2005. Review: Health Effects of Cocoa Flavonoids. Food Science and Technology International 11(3), 159-176. doi: 10.1177/1082013205054498.

Mashuni, Ramadhan, L.O.A.N., M., Jahiding, and Herniati, 2016. Analysis of diazinon pesticide using potentiometric biosensorbased on enzyme immobilized cellulose acetate membrane in gold electrode IOP Conference series: Material Science And Enginering 107(1), 1-7. doi:10.1088/1757-899X/107/1/012013

Mashuni, Nur, A.Y., Jahiding, M., and Muhamad, E., 2017a. Validation of UV-Vis Spectrophotometric Method for Determination of Bio oil Total Phenolic Content from Pyrolisis of Cashew Nut Shell, Research Journal of Pharmaceutical, Biological and Chemical Sciences 8(3), 1745-1752.

Mashuni, Jahiding M., Kurniasih, and Zulkaidah, 2017b. Characterization of Preservative and Pesticide as Potentialof Bio Oil Compound from Pyrolisis of Cocoa Shell Using Gas Chromatograph, International Conference on Chemistry, Chemical Process and Engineering 1823(1), 1-8.doi: 10.1063/1.4978081.

Mulyatni, A.S., Budiani, A., and Darmono T., 2012. Aktivitas Antibakteri Ekstrak Kulit Buah Kakao (Theobroma cacao L.) terhadap Escherichia coli, Bacillus subtilis dan Staphylococcus aureus. Jurnal Menara Perkebunan 80(2), 77-84.

Pangestu, E., Suswanto, I., and Supriyanto, 2014. Uji Penggunaan Asap Cair Tempurung Kelapa dalam Pengendalian Phytophthora sp. Penyebab Penyakit Busuk Buah Kakao secara in Vitro. Jurnal Perkebunan \& Lahan Tropika 4(2), 39-44.

Purnamawati, H., and Budi, U., 2014. Pemanfaatan Limbah Kulit Buah kakao (Theobroma cocoa L.) Sebagai Absorben Zat Warna Rhodamin B. Seminar Nasional Fisiska dan Pendidikan Fisika 5(1), 12-18.

Rachmawaty, Mu'nisa, A., Hasri, Halifah P., Hartati, and Zulkifli, M., 2018. Active Compounds Extraction of Cocoa Pod Husk (ThebromaCacao 1.) and Potential as Fungicides. Journal of Physics 1028, 1-8. doi :10.1088/1742-6596/1028/1/012013.

Rappoport, Z., 2004. The chemistry of phenols. John Wiley \& Sons.

Sharma, G., and Pandey, R.R., 2014. Influence of Culture Media on Growth, Colony Character and Sporulation of Fungi Isolated from Decaying Vegetable Wastes. Journal of Yeast and Fungal Research 1(8), 157-164.

Suharto, K.F., Soetjipto, H., and Martono, Y., 2017. Pengaruh Lama Fermentasi Tempe Terhadap Kandungan Total. ALCHEMY Jurnal Penelitian Kimia 13(2), 230-240.

Wijaya, M., Noor, E., Irawadi, T.T., and Pari, G., 2014. Karakterisasi komponen kimia asap cair dan pemanfaatannya sebagai biopestisida. Bionature 9(1), 34-40.

Wijaya, M., Wiharto, M., and Anwar, M., 2017. Kandungan Selulosa Limbah Kakao Dan Analisis Kandungan Kimia Asap Cair Kulit Kakao dengan Metode GC-MS. Jurnal Kimia Dan Pendidikan Kimia, 2(3), 191-197.

Yaman, S., 2004. Pyrolysis of biomass to produce fuels and chemical Feedstocks. Energy Conversion and Management 45(5), 651-671.doi:10.1016/S0196-8904(03)001778. 